\title{
STUDIES ON POSSIBILITIES OF INCREASING THE IMPACT RESISTANCE OF KTO ROSOMAK
}

\author{
Wacław Borkowski, Piotr Rybak, Zdzisław Hryciów, Józef Wysocki \\ Military University of Technology \\ ul. Kaliskiego 2, 00-908 Warszawa, Poland \\ tel.: +4822 6897752, fax: +48226837370 \\ e-mail:prybak@wat.edu.pl
}

\begin{abstract}
Military vehicles are mostly designed in order to provide effective execution of tasks in regions of expected actions and operation conditions. During execution of projects, resulting from participation in peace making and stabilization missions, military vehicles are subject to the impact of various mines and improvised explosives. In many cases, the explosive material mass included in the explosive charges affecting the vehicles significantly exceeds the values specified in standards defining the required protection levels assumed at the design stage. The above determines the search for additional shields or energy-absorbing elements reducing the effects of such influence. Information concerning design solutions is usually classified or very limited. Majority of companies dealing with that issue provides information concerning the scope of their business, highlighting the military area thus high efficiency of their protective solutions, possibly presenting a general outline of a particular solution. This paper presents selected results of analyses and studies being carried out and obtained results of solutions to problems included in the study tasks covering a considered subject. Proposed solutions of protective shields against mines and IED for the KTO Rosomak are presented.
\end{abstract}

Keywords: wheeled armoured carrier, loads, mine explosion

\section{Introduction}

Vehicles making the equipment of the armies are designed for efficient and effective execution of expected tasks. Regardless of regions of operation, operation conditions (terrain and weather) they have to provide a required level of safety for soldiers. During execution of tasks resulting from participation in the combat missions, including peace making and stabilization missions, military vehicles are subject to the influence of various types of mines and improvised explosive discharges (IED). In many cases of that type the explosive material mass included in the charges affecting the vehicles significantly exceeds the values specified in standards defining required levels of protection assumed at the design stage. The above determines the specialist companies and designers to search for additional shields or energy-absorbing components reducing the effects of such influence. General information is usually available in advertising materials. However, the information on design solutions is usually classified or vestigial. Majority of companies dealing with that issue provides information concerning the scope of their business, highlighting the military area thus high efficiency of their protective solutions, possibly presenting a general outline of a particular solution.

\section{Review of design solutions for components and additional shields}

This paper [3] presents the issues concerning the use of advanced technologies in the area of third generation passive armour using nanoceramics. Some results and experiments obtained during execution of works on the shields for such platforms as Leopard 2, Strv 122, KTO Fuchs (Rheinmetall), LMV (Iveco), ASV (Textron), CV90 (BAE Systems) and LAV Stryker (GDLS) are presented. Figure 1 illustrates the spherical vehicle protection concept [3] presented in this paper. 


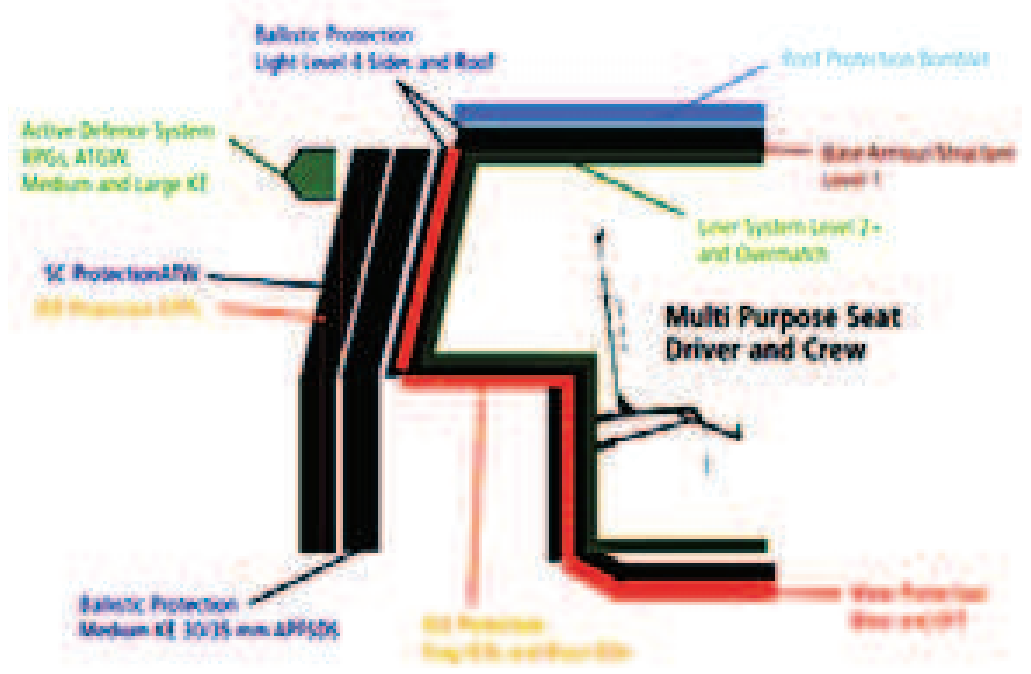

Fig. 1. Modular spherical protection concept [3]

This paper [4] presents a possibility of using protective structures consisting of components placed on a loaded surface in a form of a flat plate, $13^{\circ}$-angle hood-shaped component and a pyramid of wall inclination angle of $13^{\circ}$ as well, as shown in fig. 2.

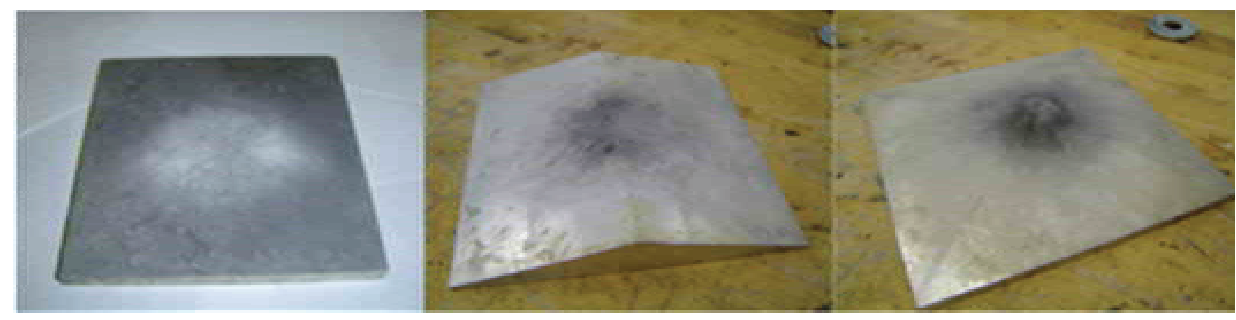

Fig. 2. Shapes of components: flat plate, $13^{\circ}$ inclination angle hood, single pyramid with $13^{\circ}$ wall inclination angle [4]

Protective plates according to the description included in [4] consisting of profile components, in a form of pyramids of various dimensions, are presented in fig. 3. Results of performed tests indicate that the structure efficiency depends on a shape and geometry of components placed on a loaded surface.

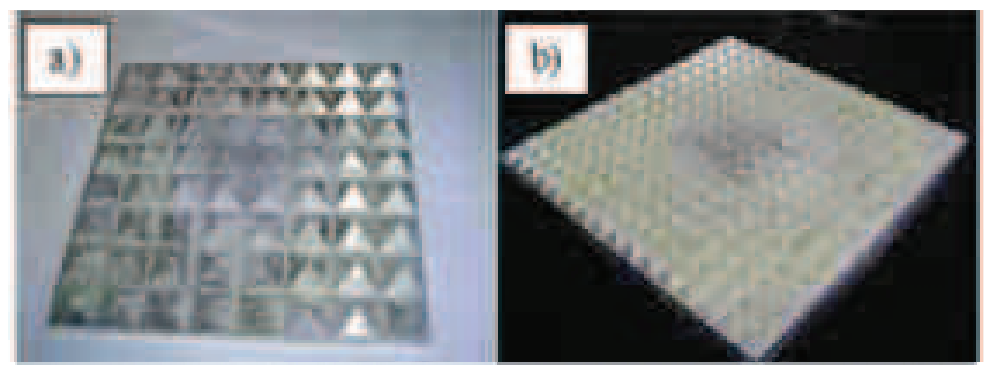

Fig. 3. View of tested protective structures [4]

A diagram of a protective panel for vehicles, U.S. patent, is shown in fig. 4 [9]. That system protects the vehicle passengers in areas where the land mines or IED occur. In the preferred solution, the protection system consists of a passive membrane, reactive block and reactive block cover. It has been designed in a way to disperse, neutralize and redirect the explosion energy, fragments and pieces, thus providing safety for the vehicle users. 


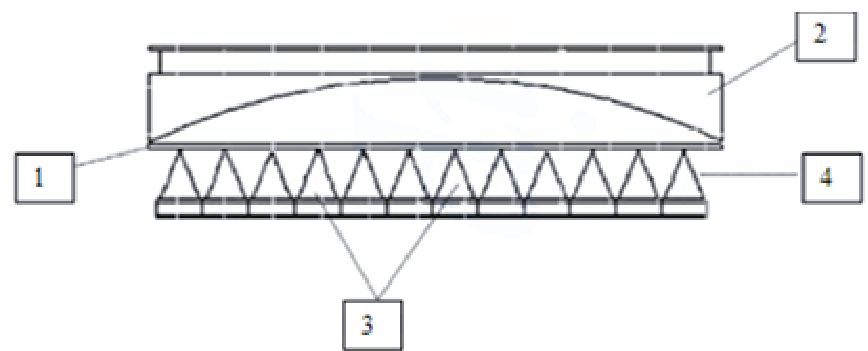

Fig. 4. Protective panel diagram: 1 -deformable membrane, 2 -chambers, 3 -reactive blocks, 4 -upper part of the reactive block [9]

Fig. 5 presents modular armour solutions by FlexKit used for protection of crew compartments in wheeled vehicles and fig. 2.31 shows modular composite armour for the same class of vehicles manufactured by O'Gara.
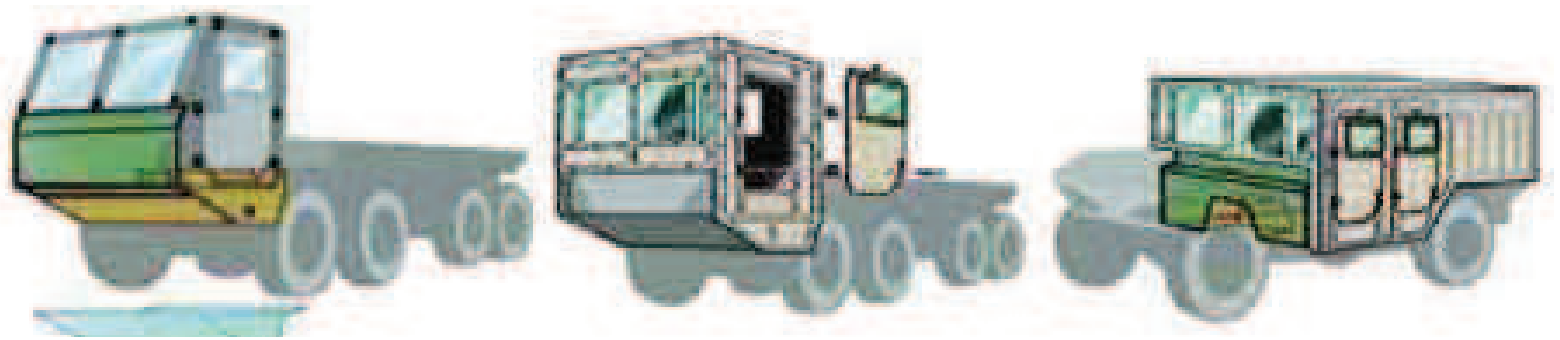

Fig. 5. Modular armour FlexKit (Ceradyne Inc. USA)

According to Iveco's information brochure [12], they have developed a complex protection of a car body for a $4 \times 4$ LMV (Light Multirole Vehicle), including protection against the land mines at the level of 4 Stanag, a mine which explodes under the wheels (not under the vehicle bottom). Figure 6 presents an outline of the modular vehicle protection.

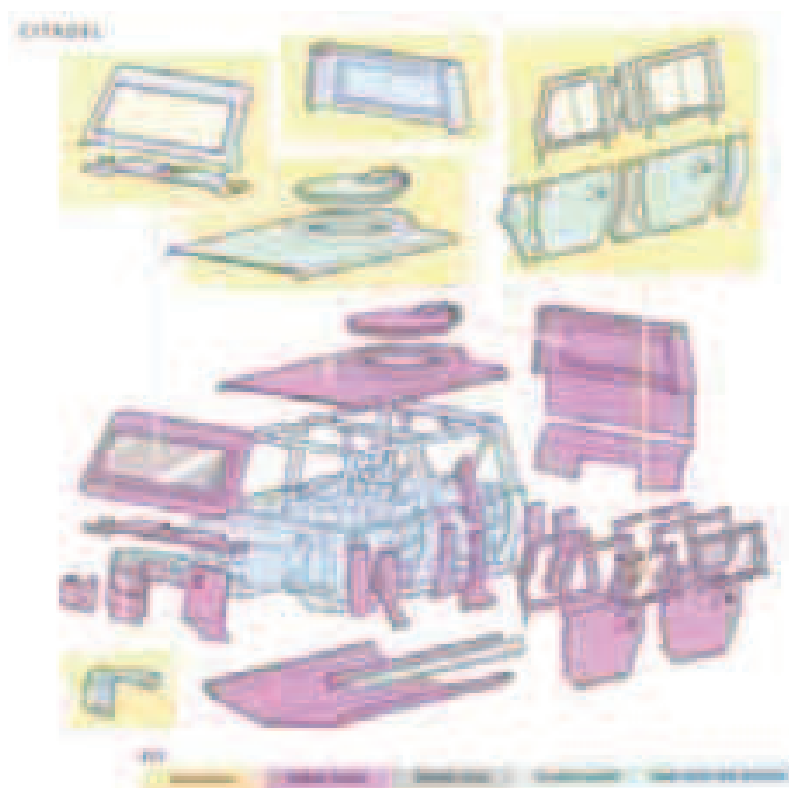

Fig. 6. Outline of modular protection in Iveco LMV vehicle [12]

Oshkosh Corporation [13] decided to upgrade the protection level of transport vehicles by using additional shield (B-kit). According to their opinion, the armour allows for adjusting the vehicle protection to the level of expected threat. Figure 7 presents a vehicle and figure 9 shows proposed protection solutions installed in vehicles. 


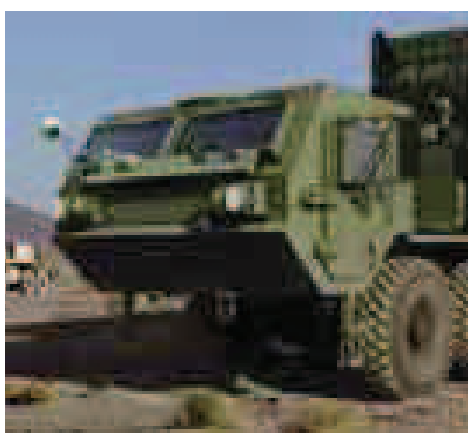

Fig. 7. Oskosh A4 HEMTT - heavy tactic vehicle with increased mobility "B kit"shield [13]

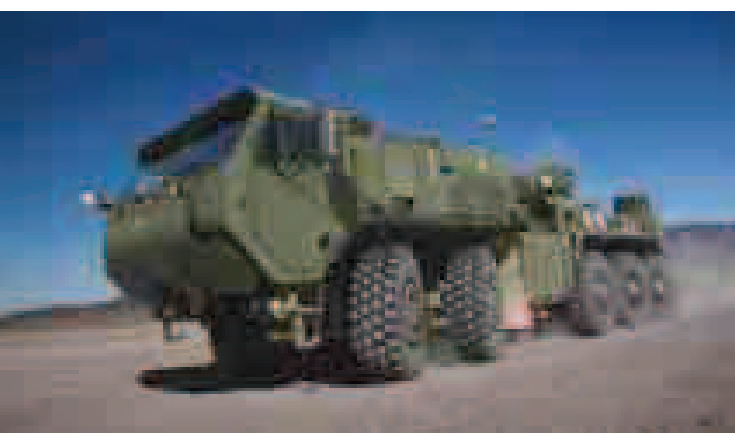

Fig. 8. Oshkosh LVSR Wrecker with increased cabin protection [13]

A British company, Aigis Blast Protection Ltd, presents and offers protection named TABREarmour ${ }^{\circledR}$. It is made of a patented material, which guarantees protection level of $2-4$ (according to Stanag 4569), according to their opinion, it absorbs all elements of explosion and provides $40 \%$ impulse reduction, $70 \%$ deformation reduction, $90 \%$ overpressure reduction.

Protective plate made of a presented material before and after the tests are presented on fig. 9, however fig. 10 presents complete additional armour for a wheeled vehicle.
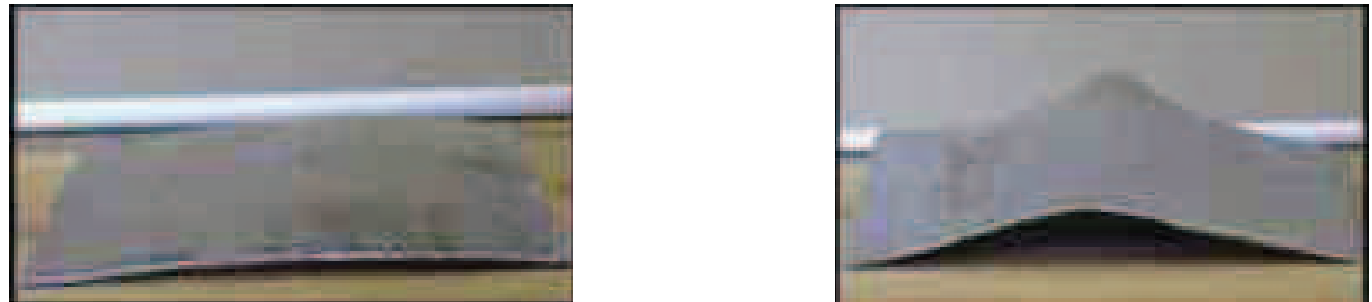

Fig. 9. A plate made of TABREarmour ${ }^{\circledR}$ material before and after the tests [Aigis Blast Protection Ltd UK]
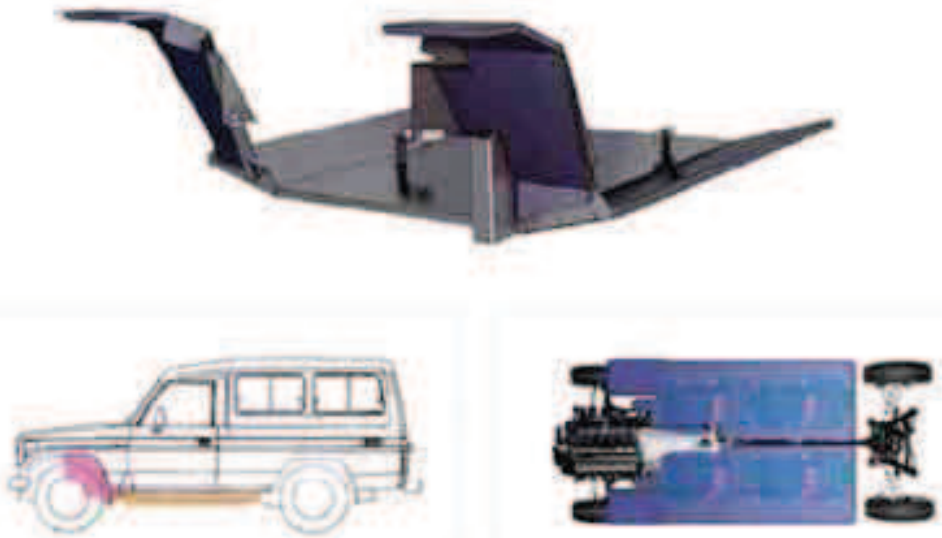

Fig. 10. Shape and arrangement of additional protection elements before the explosion of mines and IED [Aigis Blast Protection Ltd UK]

Some elements of protection against explosion used in Russian wheeled vehicles (e.g. Kamaz and others) are presented on fig. 11, on the basis of a photo shown on a website [www.btvt.narod.ru]. These are mostly steel protective elements of full or openwork with holes of various shapes and arrangement.

This paper [14] describes an original, energy-absorbing protective panel of complex geometry and characteristic structure. That structure has been prepared on the basis of available literature data and review of currently applied protective structures in order to absorb the explosion energy as much as possible without generating the pieces or splinters. A scheme of a structure of one of the panels is presented on fig. 12 . 


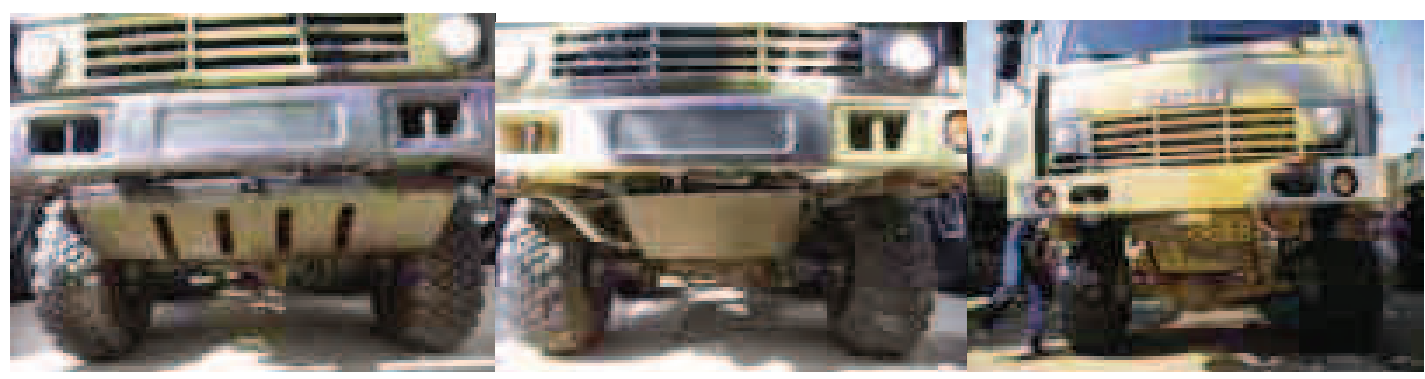

Fig. 11. Shields for driver's cabin in KAMAZ vehicle [www.btvt.narod.ru]

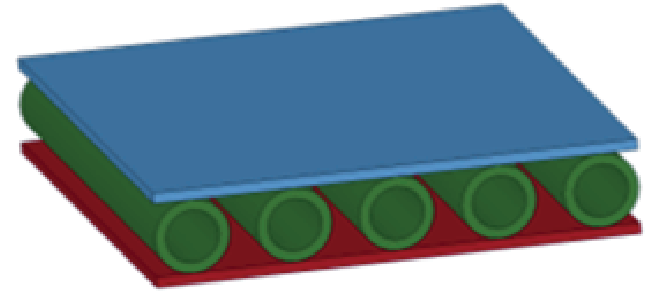

$L$

Fig. 12. Protective panel scheme [14]

Cabins of STAR trucks used or designed to be used in difficult conditions of peace-making and stabilization mission have been modernized in 3. OWT of Nowy Dwór Gdański in the aspect of increasing the protection against explosion. A deflector dispersing the explosion energy of a mine or IED has been placed under a cabin. Fig. 13 shows the photos of a vehicle with a visible deflector. The deflector solution was presented during the 2009 International Defence Industry Show in Kielce, Poland [15].

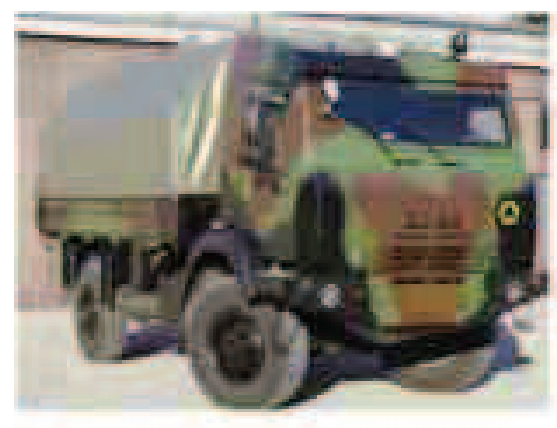

Picaire [3 OWT Nowy Dwar Ganiski]

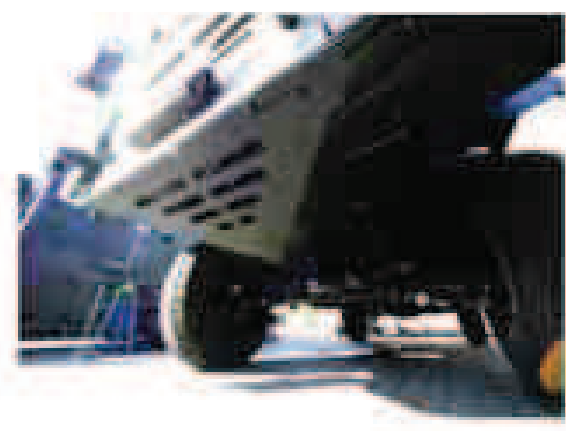

Pisanel (15)

Fig. 13. Star armoured vehicles with a visible shape deflector [15]

This paper [17] presents one of the ways of protecting the vehicles with framed supporting structure. An original protection component, developed by the authors, makes a flat plate of defined thickness. Holes of assumed shapes are made in its surface. The plate is fixed to a vehicle frame. Figure 14 presents a protective plate after model and numerical tests.
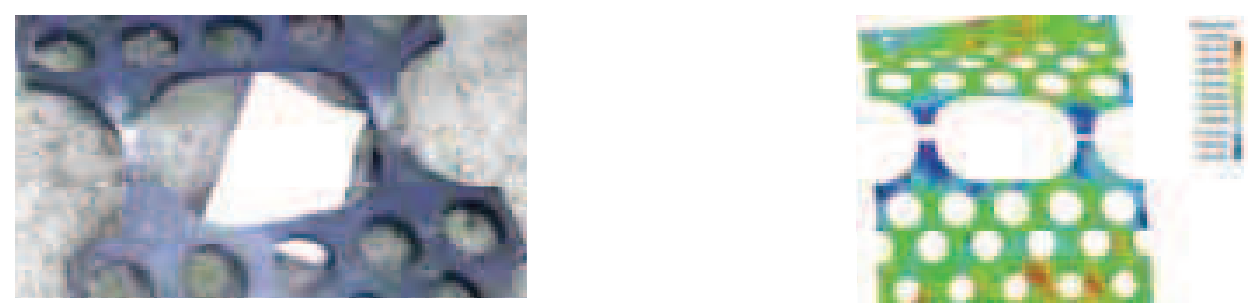

Fig. 14. A view of a protective plate after military field tests and numerical calculations [17] 


\section{Proposed solutions of protective shields against mines and IED for KTO}

The analysis of design solutions of additional shields for KTO has been carried out in two aspects. The first one concerns protection against mines and the second one refers to protection against side explosives. Regardless of the aspect of the analysis, limitations and conditions resulting from vehicle structure features and its susceptibility to modernization should be considered. A basic issue, which should be assumed, is to reduce the weight of protective components as much as possible at highest possible dispersion efficiency indexes or explosion energy absorption indexes without deterioration of vehicle mobility in any conditions. Dimensions, particularly the width of shields to be used, make the main restriction in KTO structure. That restriction mostly refers to protection against mines. Therefore, we propose to use the following additional shields.

\subsection{Bottom shields}

For the protection against mines, the use of two types of shields is proposed. In areas, where possible due to occurring structural limitations (e.g. arrangement of driving bridges), use dispersing shields, properly perforated flat plates with small deflection towards the ground. They should be fixed to an integrated indirect support, as shown on fig. 15. While figure 16 presents an outline of an example of a dispersing shield. In areas where a bottom of a body is uncovered, we propose to use a steel deflector structure of selected dimensions and assumed shape. An outline of such shield is presented on fig. 17. In order to increase the protection against side explosives, we propose to use a structure made of a light alloy (its shape is shown on fig. 12) or aluminium foam in a container made of a selected material.

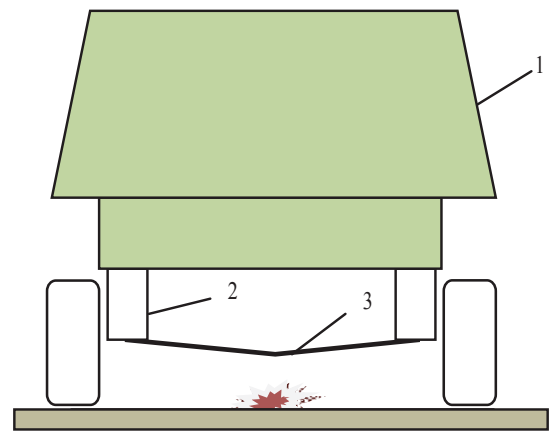

Fig. 15. Location and shape of anti-mine dispersing shield: 1 - body, 2 - integrated indirect support, 3 - dispersing shield

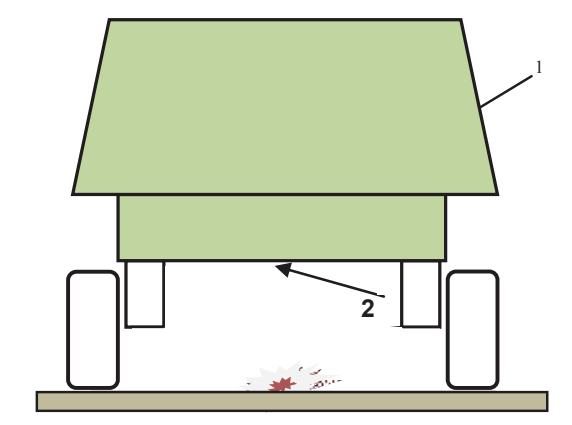

2

Fig. 16. Shape of anti-mine shield fixed to the bottom of a vehicle

\subsection{Side shields}

Side shields are usually made in a modular form of definite dimensions, simple external shapes and geometry, and are easily replaceable when damaged. Their characteristic features are a need to provide a required level of ballistic protection (against armour-piercing sabot and cumulative missiles of a set penetration) as well as resistance to the influence of side charges. Thus, a simple external structure has to include a complex protective structure (protective panel). Figure 17 presents an example of an outline of a body protective element to be used in order to reduce the efficiency of the influence of side IED explosions.

\section{Simulation tests for additional shield efficiency}

The tests have been carried out for two most often and the most dangerous incidents. The first one includes an influence of bottom-piercing mines and improvised explosives hidden in the ground. The second one includes the influence of side explosives. Therefore, in order to reduce the 
effect of the impact on the vehicle body and its internal equipment, the efficiency tests have been carried out on the bottom and side shields. Their outlines are presented in section 3.

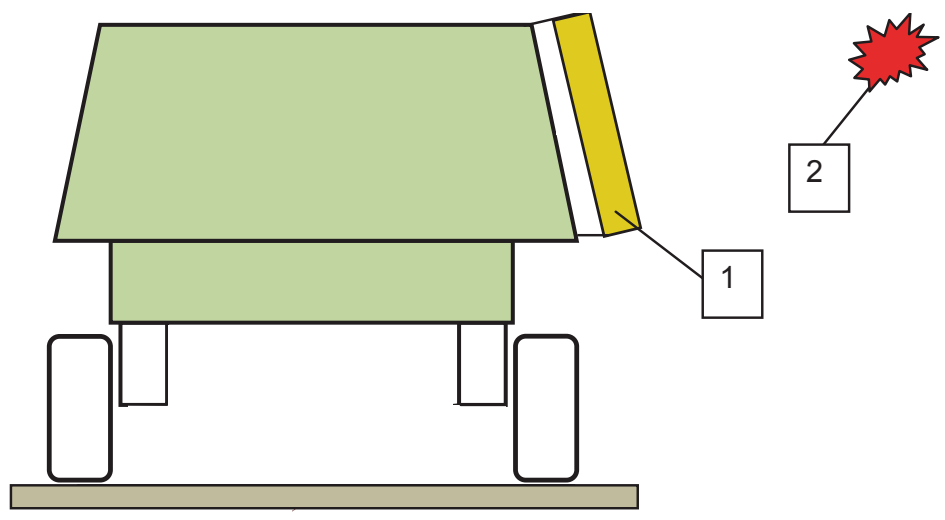

Fig. 17. Modular shield (1) fixed to a side of a vehicle as a shield against explosion of side explosives (2)

\subsection{Bottom shield efficiency tests}

Numerical calculations have been carried out for two protective structure concepts. The first one included placing a flat sheet, covering fragments of a bottom between the driving bridges, on an indirect support. That type of solution, proposed among others in [19], despite of its simplicity and installation easiness, turned out to be wrong. Due to significant reduction of a distance between a shield and an explosive (by app. 50\%), the pressure affecting the structure increases by several times. It results in an increase of destruction level for an indirect support fragments located under the shield. Additionally, thorn shield fragments hit a vehicle bottom, which causes piercing. The use of shields directly under the bottom is very difficult thus, that type of solution was omitted at that stage of analysis. The second solution was assumed for further considerations. That solution means placing and additional bottom inside a vehicle, in a driver's compartment and landing troops' compartment.

\section{a/ shield in the landing troops' compartment}

Increased protection of soldiers located in the landing troops' compartment is provided by inserting an additional bottom. It is located in parallel to the bottom and it is made of the same material as the vehicle body. The whole, consisting of smaller sheets, welded to the vehicle sides and profiles stiffening the bottom.

Fig. $18 \mathrm{a}$ and $\mathrm{b}$ presents a deformation of indirect support and vehicle bottom and deformations of an additional bottom inside a vehicle resulting from the explosion of $30 \mathrm{~kg}$ TNT under a vehicle between the $3^{\text {rd }}$ and $4^{\text {th }}$ axis of a carrier vehicle. Introduction of an additional plate increases the vehicle structure. Compared to a basic version, smaller bottom structure damages occurred. It should be underlined that additional bottom has not been pierced. The maximum vertical displacements of a middle part of additional plate amounted to about $170 \mathrm{~mm}$.

A shield in the driver's compartment, as in the previous case, has a form of steel plates welded to a left side of a vehicle body, engine compartment plate and profiles reinforcing the bottom.

Figure 19 presents damages of indirect support and lower part of the bottom, resulting from the explosion of a $25 \mathrm{~kg}$ TNT explosive placed near the first left wheel. A fragment of the support was thorn, bearings of the lower arm were detached and the bottom was pierced underneath a driver's seat. However, an inserted additional plate was not pierced and significantly reduced the bottom destruction. Figure 20 presents plastic deformations occurring in the vehicle structure. The biggest deformations of the additional plate occurred in a place where the basic bottom was pierced and where it contacts the additional plate. 
a)

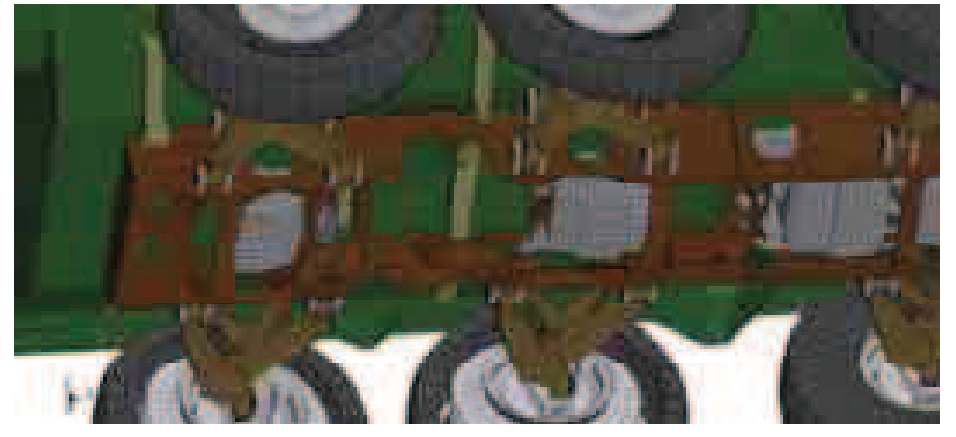

b)

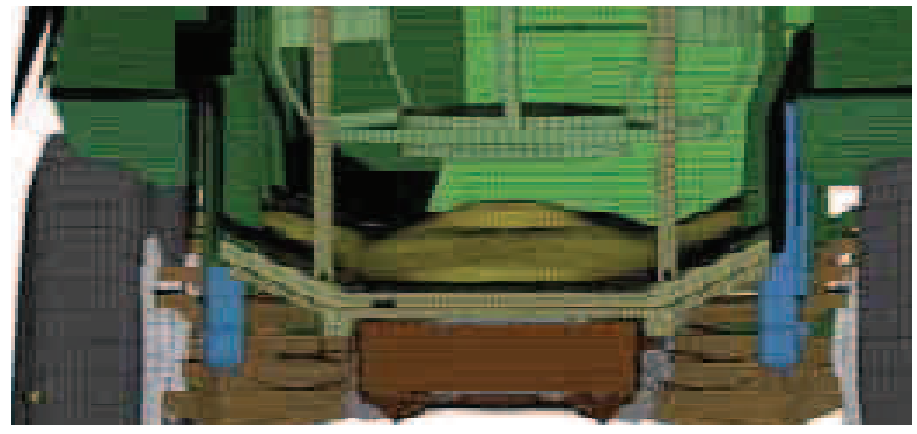

Fig. 18. Deformations of structures in the landing troops' compartment

\section{b/ shield in the driver's compartment}

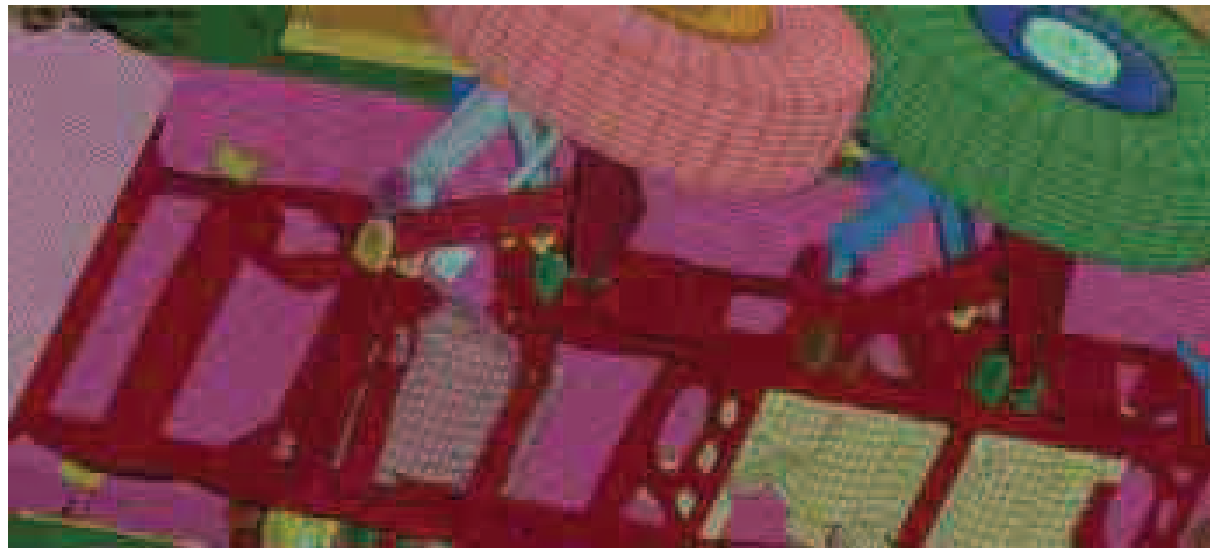

Fig. 19. Damages of indirect support and a vehicle body resulting from an explosion of a $25 \mathrm{~kg}$ TNT explosive

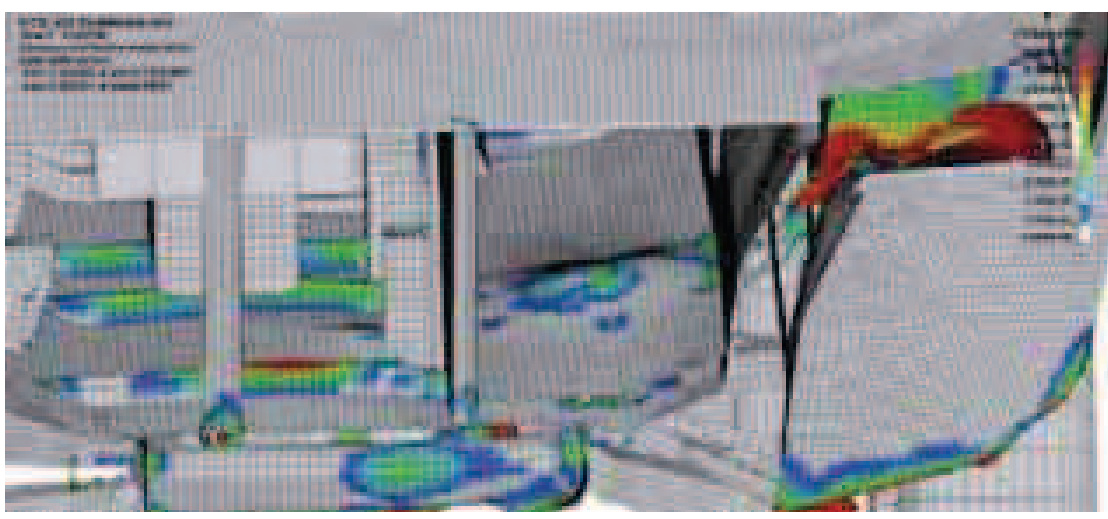

Fig. 20. Plastic deformations in the troop carrier structure 


\subsection{Side shield efficiency tests}

Troop carrier vehicles used in the country are equipped with side shields in a form of one thin plate separated from body armour by foam increasing the vehicle displacement. In case of troop carriers used in the missions, that type of protection might be insufficient. In the analysed case, the side shield efficiency test was carried out on the basis of an armour structure consisting of two steel armour plates. Plates connected by means of screws make panels that are fixed to the sides of a vehicle body. Figure 21 presents a stress of the vehicle body structures and protective panels fixed to a vehicle subject to a load cased by an explosion wave of a $20 \mathrm{~kg}$ TNT explosive placed on a vehicle side at a distance of $1 \mathrm{~m}$. The highest stresses in a vehicle body can be observed in places where protective panels are installed and where the batteries are installed. It should be underlined that the vehicle body was pierced there in case of standard armour.

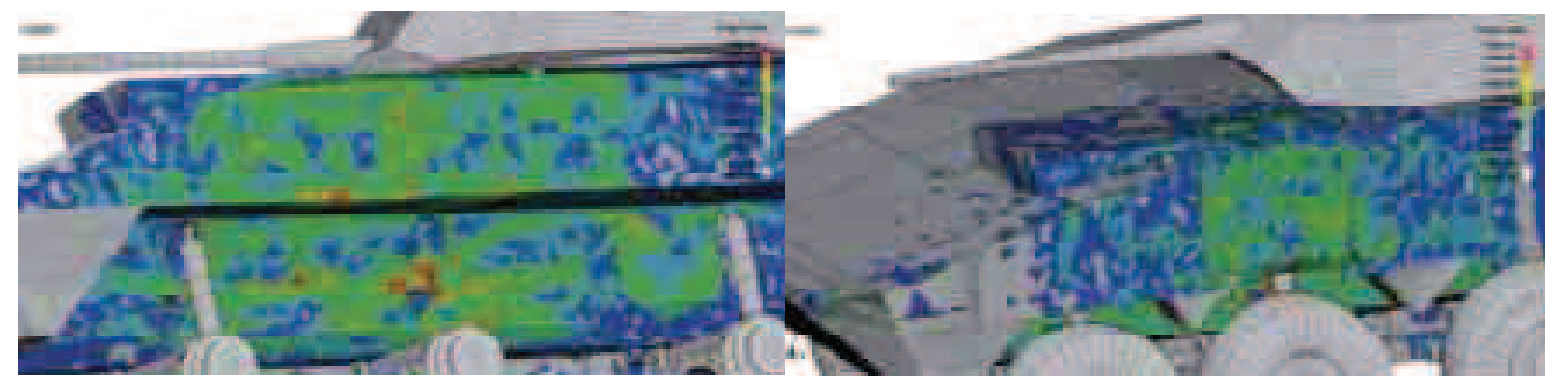

Fig. 21. Distribution of stresses on a surface of the vehicle body and protective panels

Figure 22 shows behaviour of protective panels after explosion. Their lower fragments become curved. Screw connections, connecting the panels and the vehicle body become broken and as a result, the panels are thrown away (from the first one to the fifth one).

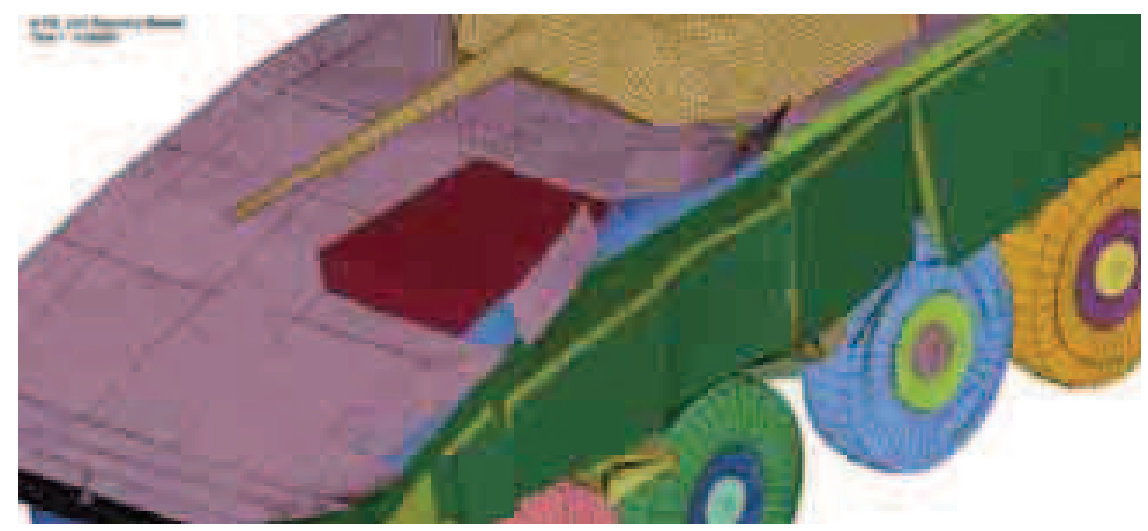

Fig. 22. A view of broken protective panels

\section{References}

[1] Schaeffler, P., Rajner, W., Claar, D., Trendelenburg, T., Nishimura ,H., Properties, and Applications of Alulight ${ }^{\circledR}$ Closed-Cell Aluminum Foams. Production, 2005.

[2] Tabiei, A., Nilakantan, G., Reduction of Acceleration Induced Injuries from Mine Blasts under Infantry Vehicles. Dept. Of Aerospace Engineering and Engineering Mechanics University of Cincinnati, OH 45221, USA.

[3] Rust, M., Passive Protection Concepts. IBD Deisenroth Engineering.

[4] Genson, K., Vehicle shaping for mine blast damage reduction. Aerospace Engineering Department, 2006.

[5] Castanie, B., Bouvet, C., Aminanda, Y., Barrau, J. J., Thevenet, P., Modelling of lowenergy/low-velocity impact on Nomex honeycomb sandwich structures with metallic skins. International Journal of Impact Engineering 35 (2008). 
[6] Guruprasad, S., Mukherjee A,, Layered sacrificial claddings under blast loading Part II experimental studies. International Journal of Impact Engineering 242000.

[7] Hanssen, A. G., Enstock, L., Langseth, M., Close-range blast loading of aluminium foam panels. International Journal of Impact Engineering 272002.

[8] Light Improved Ballistic Armor (LIBA). Materiały firmy Mofet Etzion Yehuda, Defense Updated Internationale Online Defence Magazine. 2006.

[9] Patent USA US 8,025,005 B2 Sept. 27.2011, http://ip.com/patent/US8025005.

[10] Torre, L., Kenny, J. M., Impact testing and simulation of composite sandwich structures for civil transportation. Materials Engineering Center, University of Perugia, Loc Pentima Bassa 21, 05100 Terni, Italy 2000.

[11] Jiang, D., Liu, Y., Qi, Ch., Ma, Z. D., Raju, B., Bryzik, W., Innovative Composite Structure Design for Blast Protection. SAE Technical Paper Series 07MV-6.2007.

[12] Iveco Defence Vehicles LMV 4x4. Materiały reklamowe.

[13] http://defense-update.com/20110408_underbody_protected_hemtt.html.

[14] Rybak, P., Protecting panels for special purpose vehicles. Journal of Kones and Powertrain vol. 17, nr 1/2010, Warszawa2010.

[15] Pancerny Star, e-RAPORT MSPO 3/2009.

[16] www.magnum-x.pl, Nowa Technika Wojskowa nr 3/2010.

[17] Rusiński, E., Iluk, A., Ptak, M., Wybrane zagadnienia w modelowaniu obciążeń udarowych. XII Konferencja Naukowo-Techniczna Techniki Komputerowe w Inżynierii Słok k. Bełchatowa 2011.

[18] Kolenda, J., Stanowisko do badania energochłonności osłon. Zeszyty Naukowe AMW, rok XLX Nr 2 (177) 2009.

[19] Kiński, A., Sitarski, M., współpraca Miernik, R., Rosomak okiem użytkowników. Nowa Technika Wojskowa Nr1/2012.

Scientific work financed from resources for science in years 2010 - 2012as research project. 